\title{
Effect of Resin Impregnation Ratio on the Properties of Ceramics Made from Miscanthus sinensis var. purpurascens Particle Boards ${ }^{1}\left(\mathbb{A P}_{0}\right)$
}

\author{
Jung-Woo HWANG ${ }^{2} \cdot$ Hee-Jun $\mathrm{PARK}^{3} \cdot$ Seung-Won OH(D)
}

\begin{abstract}
For the purpose of finding new uses for Miscanthus sinensis var. purpurascens, this study first constructed boards with the particles of the plant and impregnated them with phenolic resin at resin impregnation rates of $30 \pm 2 \%, 40 \pm 2 \%$, $50 \pm 2 \%$, and $60 \pm 2 \%$. The impregnated boards were then carbonized at the carbonization temperature of $800{ }^{\circ} \mathrm{C}$, after which their density and mechanical properties were examined according to the different resin impregnation rates. The results showed that density, flexural strength performance, Brinell hardness, and compressive strength increased as the resin impregnation rate increased, thus affecting the physical and mechanical properties of the ceramics made of $M$. sinensis var. purpurascens particles.
\end{abstract}

Keywords: Miscanthus sinensis var. purpurascens, resin impregnation ratio, density, bending strength, compression strength and brinell hardness

\section{INTRODUCTION}

In general, ceramics are sintered bodies, such as pottery or porcelain that are made of clay or minerals, while a broader definition includes inorganic materials with ionic and covalent bonds. According to this, carbon is certainly included in the category of ceramics. Therefore, porous carbon materials obtained by carbonizing composite materials, such as wood and thermosetting resin or ceramics obtained from wood, were named "wood ceramics" (Okabe, 1996).

Various studies on the manufacturing of ceramics have been conducted since Okabe and Saito (1995) developed a new porous carbon material by impregnat- ing a wooden material with phenolic resin and thermoforming it in a vacuum (Hirose et al., 2002; Iizuka et al., 1999; Zhao et al., 2002). The physical properties of wood ceramics vary depending on the type of raw material, impregnation rate of the thermosetting resin, and manufacturing conditions such as carbonization temperature and rate of temperature increase. Especially, resin impregnation rate and carbonization temperature are known to greatly affect the density of wood ceramics (Hirose et al., 2002; Oh et al., 2004, 2010).

Meanwhile, the insufficiency of wood resources led to the research on using nonwood resources for board manufacturing and ceramicization, and one prominent example of such research involved the development

\footnotetext{
${ }^{1}$ Date Received April 6, 2021, Date Accepted July 2, 2021

2 Department of Wood Science and Technology, Jeonbuk National University, 54896, Jeonju, Republic of Korea

${ }^{3}$ College of Human Ecology, Jeonbuk National University, Chonju, 54896, Jeonju, Republic of Korea

$\dagger$ Corresponding author: Seung-Won OH (e-mail: ohsw@jbnu.ac.kr, ORCID: 0000-0002-6601-9789)
} 
Effect of Resin Impregnation Ratio on the Properties of

Ceramics Made from Miscanthus sinensis var. purpurascens Particle Boards

of a new material using a mixture of rice husk and lignocellulosic materials (Lee and Han, 2000; Lee, 1999; Oh and Byeon, 2005; Hwang and Oh, 2020a). Research was also conducted on utilizing various byproducts and wastes (Hwang and Oh, 2019; Hwang and Oh, 2020b; Ju and Roh, 2019; Ju and Roh, 2020).

Among them, Miscanthus sinensis var. purpurascens is a lignocellulosic material with a high porosity and low specific gravity, and being a renewable resource like wood, it can be used as a highly valuable resource in terms of resource use and circulation. In addition, the M. sinensis var. purpurascens boards produced with liquid phenolic resin had similar flexural strength but superior peel strength when compared to the boards made of powdery phenolic resin (Oh et al., 2012). Because of these advantages, the effective use of $M$. sinensis var. purpurascens is being actively studied (Kim et al., 2012; Oh et al., 2012; Park et al., 2012; Oh et al., 2014).

In this context, this study used $M$. sinensis var. purpurascens, which could be a valuable resource for realizing green growth in the 21 st century, in manufacturing particle boards. The boards were then impregnated at various ratios and carbonized at a constant temperature for each resin impregnation rate for ceramicization, after which their density and mechanical properties were examined.

\section{MATERIALS and METHODS}

\subsection{Test materials}

\subsubsection{M. sinensis var. purpurascens}

M. sinensis var. purpurascens used to manufacture the boards was obtained from the Bioenergy Crop Center, National Institute of Crop Science, Rural Development Administration located at Muan, Jeollanam-do, Korea. To ensure uniformity of samples, particle size was selected from 10 mesh to 20 mesh and moisture content was adjusted to $7 \%$ or less, as shown in Fig. 1.

\subsubsection{Resin}

Powdered phenolic resin (KNB-100PL from Kolon Chemicals Co., Ltd.) was used for manufacturing $M$. sinensis var. purpurascens board, and liquid phenolic resin (KPD-L777 from Kolon Chemicals Co., Ltd.) was used for impregnation. Table 1 shows the characteristics of each resin.

\subsection{Production of boards}

The manufacturing process for the boards is as follows. The powdered phenolic resin was sufficiently mixed with the uniformly selected $M$. sinensis var. purpurascens particles, and the mixture was then put into a stainless square mold on the heating plate of the hot press, where the height of the top part of the sample was adjusted to be even. Then, a board with the dimensions of $26 \mathrm{~cm} \times 26 \mathrm{~cm} \times 1.4 \mathrm{~cm}$ was produced by hot press molding. In terms of manufacturing

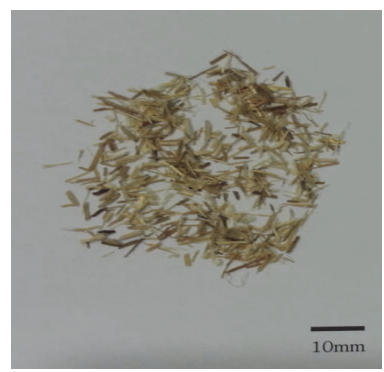

Fig. 1. Shape of Miscanthus sinensis var. purpurascens.

Table 1. Characteristics of phenol-formaldehyde resin for the test

\begin{tabular}{c|c|c}
\hline Resin types Items & $\begin{array}{c}\text { Powder resin } \\
\text { (Novolak type) }\end{array}$ & $\begin{array}{c}\text { Liquid resin } \\
\text { (Resol type) }\end{array}$ \\
\hline \hline Solid content $(\%)$ & 99 & $51-53$ \\
Melting point $\left({ }^{\circ} \mathrm{C}\right)$ & $80 \sim 95$ & \\
Specific gravity & - & 1.06 \\
Gelation time (sec.) & $80 \sim 120$ & $80-95$ \\
Plate flow (mm) & $30 \sim 35$ & \\
Viscosity (cps) & - & $45-65$ \\
\hline
\end{tabular}


Jung-Woo HWANG $\cdot$ Hee-Jun PARK $\cdot$ Seung-Won OH

conditions for the board, the density was set to be 600 $\mathrm{kg} / \mathrm{m}^{3}$ and amount of added adhesive was fixed at $10 \%$. The hot press temperature was $190^{\circ} \mathrm{C}$, pressing pressure was $3.9 \mathrm{MPa} \rightarrow 2.9 \mathrm{MPa} \rightarrow 1.9 \mathrm{MPa}$ (3-stage pressing), and pressing time was $3 \mathrm{~min} \rightarrow 2 \mathrm{~min} \rightarrow$ 1 min (3-stage pressing time). A stopper (distance bar) was used to keep the thickness of the board constant during the hot pressing process, and a Teflon plate was used to prevent the attachment of the top and bottom of the board to the hot plate by heat.

\subsection{Impregnation and production of ceramics}

The M. sinensis var. purpurascens boards were cut to the size of $12 \mathrm{~cm} \times 12 \mathrm{~cm} \times 1.4 \mathrm{~cm}$, put in a pressure-reducing impregnation device containing liquid phenolic resin (KPD-L777 from Kolon Chemicals Co., Ltd.), and impregnated at $1 \mathrm{~atm}$ with impregnation rates of $30 \pm 2 \%, 40 \pm 2 \%, 50 \pm 2 \%$, and $60 \pm 2 \%$. After impregnation, the samples were placed in a dryer to be dried and cured for $10 \mathrm{~h}$ at $60^{\circ} \mathrm{C}$, and at $100^{\circ} \mathrm{C}$ and $135^{\circ} \mathrm{C}$ for $8 \mathrm{~h}$ each. After drying, the ceramics were produced via carbonization at a carbonization temperature of $800^{\circ} \mathrm{C}$ using a vacuum carbonization furnace (KOVAC KSF-200V from Korea Vacuum Co., Ltd.). At this time, the rate of temperature increase was $4{ }^{\circ} \mathrm{C} / \mathrm{min}$, and the temperature was main-

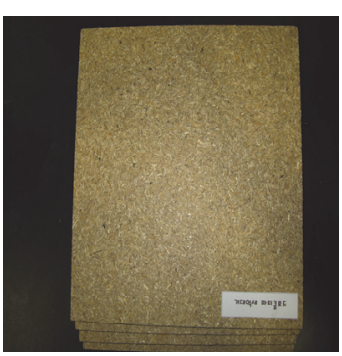

(a)

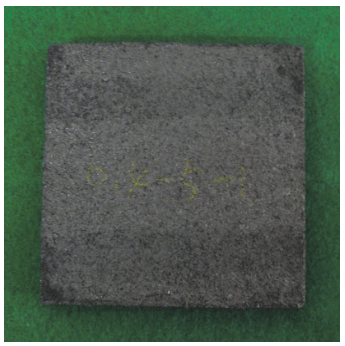

(b)
Fig. 2. Appearance of the composite (a)board and (b) ceramic manufactured from Miscanthus sinensis var. purpurascens. tained at the target temperature for $2 \mathrm{~h}$ before cooling down. Fig. 2 shows pictures of the finished boards and ceramics.

\subsection{Strength performance test}

For flexural strength performance test, the specimen was cut in $110 \mathrm{~mm} \times 10 \mathrm{~mm} \times 10 \mathrm{~mm}$ and humidified in a thermo-hygrostat (temperature at $20 \pm 1{ }^{\circ} \mathrm{C}$, humidity at $65 \pm 5 \%$ ), after which we selected 10 pieces for each test condition of the flexural strength performance test. The flexural strength test was performed by using a universal strength tester (model TSU-2 from TAESHIN) at the loading rate of 0.5 $\mathrm{mm} / \mathrm{min}$ to measure the flexural modulus and flexural strength in compliance with the KS F 2208 standard. For the Brinell hardness test followed the KS F 2212 standard by using a universal strength tester in pressing a $10 \mathrm{~mm}$-diameter iron bead into three points on the surface of the samples of wood ceramics with the size of $40 \mathrm{~mm} \times 40 \mathrm{~mm} \times 10 \mathrm{~mm}$ at the loading rate of $0.5 \mathrm{~mm}$ and pressing depth of $1 / \pi \mathrm{mm}$. In accordance with the KS F 2206 standard, the compressive strength test was performed on a $30 \mathrm{~mm} \times 10 \mathrm{~mm}$ $\times 10 \mathrm{~mm}$ specimen at a loading rate of $0.5 \mathrm{~mm} / \mathrm{min}$ using a universal strength tester.

\section{RESULTS and DISCUSSION}

\subsection{Density}

As for the densities of the resin-impregnated ceramics boards with resin impregnation rates of $30 \pm$ $2 \%, 40 \pm 2 \%, 50 \pm 2 \%$, and $60 \pm 2 \%$ before carbonization which then went through carbonization at $800^{\circ} \mathrm{C}$, Table 2 and Fig. 3 show them to be 558.57, 617.08, 627.10 , and $649.10 \mathrm{~kg} / \mathrm{m}^{3}$, respectively. This indicates that the density after carbonization increased as the resin impregnation rate increased at the fixed carbonization temperature. 
Effect of Resin Impregnation Ratio on the Properties of

Ceramics Made from Miscanthus sinensis var. purpurascens Particle Boards

Table 2. The physical and mechanical properties of ceramics made at different carbonization temperature

\begin{tabular}{c|c|c|c|c|c|c}
\hline $\begin{array}{c}\text { Impregnation } \\
\text { rate }(\%)\end{array}$ & $\begin{array}{c}\text { Temperature } \\
\left({ }^{\circ} \mathrm{C}\right)\end{array}$ & $\begin{array}{c}\text { Density } \\
\left(\mathrm{kg} / \mathrm{m}^{3}\right)\end{array}$ & $\begin{array}{c}\text { MOR } \\
(\mathrm{MPa})\end{array}$ & $\begin{array}{c}\text { MOE } \\
(\mathrm{GPa})\end{array}$ & $\begin{array}{c}\text { Brinell hardness } \\
(\mathrm{MPa})\end{array}$ & $\begin{array}{c}\text { Compression strength } \\
(\mathrm{MPa})\end{array}$ \\
\hline \hline 30 & 800 & $558.57(30.63)$ & $2.76(0.83)$ & $1.21(0.31)$ & $5.11(0.85)$ & $3.44(1.18)$ \\
40 & 800 & $617.08(49.90)$ & $3.25(0.75)$ & $1.63(0.34)$ & $7.15(1.58)$ & $5.09(1.35)$ \\
50 & 800 & $627.10(29.84)$ & $3.30(0.97)$ & $1.66(0.39)$ & $6.85(1.72)$ & $6.73(2.11)$ \\
60 & 800 & $649.10(30.15)$ & $3.74(0.95)$ & $1.82(0.41)$ & $7.55(2.39)$ & $9.65(2.35)$ \\
\hline
\end{tabular}

Parenthesis is standard deviation; MOE: modulus of elasticity; MOR: modulus of rupture; Mean value from 10 replications;

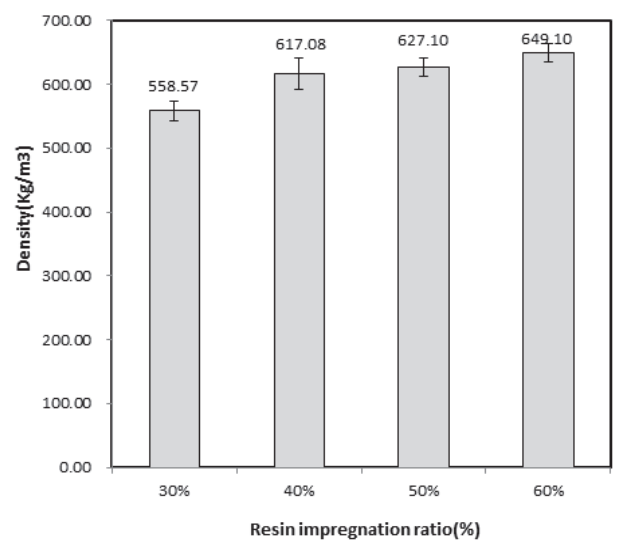

Fig. 3. Density of ceramics according to resin impregnation ratio at carbonization temperature $800^{\circ} \mathrm{C}$.

Oh and Piao (2004) also reported that when the resin impregnation rate before carbonization of the board made of thinned logs was $40 \%$, the density values of wood ceramics of Pinus densiflora, Larix kaempferi, and Pinus koraiensis were 760,730 , and $750 \mathrm{~kg} / \mathrm{m}^{3}$, respectively. When the resin impregnation rate before carbonization was higher (at $80 \%$ ), the densities of wood ceramics made from thinned logs of Pinus densiflora and Larix kaempferi were higher at 830 and $840 \mathrm{~kg} / \mathrm{m}^{3}$, respectively, thus showing a similar trend to the results of this study. In addition, it was also reported that the density tended to increase following the increase in the resin impregnation rate in the manufacture of wood ceramics using medium-density fiberboard (MDF) made from Pinus radiata ( $\mathrm{Oh}$ and Byeon, 2002; Oh, 2005). The positive correlation be-

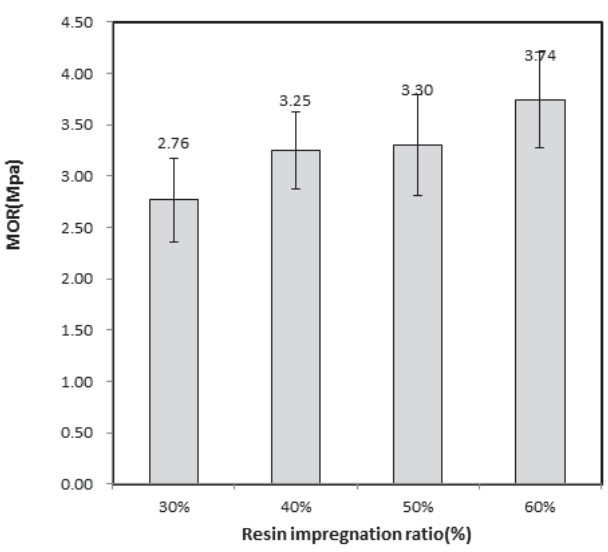

Fig. 4. MOR of ceramics according to resin impregnation ratio at carbonization temperature $800^{\circ} \mathrm{C}$.

tween the resin impregnation rate before carbonization and the density of wood ceramics thereafter is believed to be stemming from the fact that the large amount of resin impregnated in the cell walls is converted into vitreous carbon during the carbonization process to strengthen the cell walls, thus resulting in the density increase (Okabe and Saito, 1995).

\subsection{Flexural strength}

Table 2 and Fig. 4 show the flexural strength values depending on the resin impregnation rate of ceramics carbonized at $800^{\circ} \mathrm{C}$ carbonization temperature. When the resin impregnation rate was $30 \pm 2 \%, 40 \pm 2 \%$, $50 \pm 2 \%$, and $60 \pm 2 \%$ at the carbonization temperature of $800^{\circ} \mathrm{C}$, the flexural strength values were 2.76 , 
3.25, 3.30, and 3.74 $\mathrm{MPa}$, respectively, indicating that the flexural strength tended to increase almost linearly as the resin impregnation rate increased, similar to the trend in density.

This trend is consistent with the previous reports that the flexural strength increased linearly as the resin impregnation rate increased even in the manufacture of wood ceramics using MDF made from Pinus radiata (Oh and Byeon, 2002; Oh, 2005). In addition, there was a difference in the resin impregnation rate and carbonization temperature conditions depending on the density of the tree species. The flexural strengths of Pinus radiata at the carbonization temperature of $600^{\circ} \mathrm{C}$ under the similar resin impregnation rate conditions of $40 \%$, 60\%, and $80 \%$ were $6.96 \mathrm{MPa}, 8.04 \mathrm{MPa}, 13.44$ $\mathrm{Mpa}$, respectively, and these values were higher than those of this study with $M$. sinensis var. purpurascens particles.

Moreover, Oh and Byeon (2005) reported that when the phenolic resin impregnation rates were $40 \%, 50 \%$, $60 \%$, and $70 \%$ at the carbonization temperature was $600{ }^{\circ} \mathrm{C}$ for the mixed ceramics made of sawdust and rice husk, their flexural strength values were 4.70, 4.90, 5.98, and 6.08 Mpa, respectively, which were slightly higher than the values of the ceramics in the current

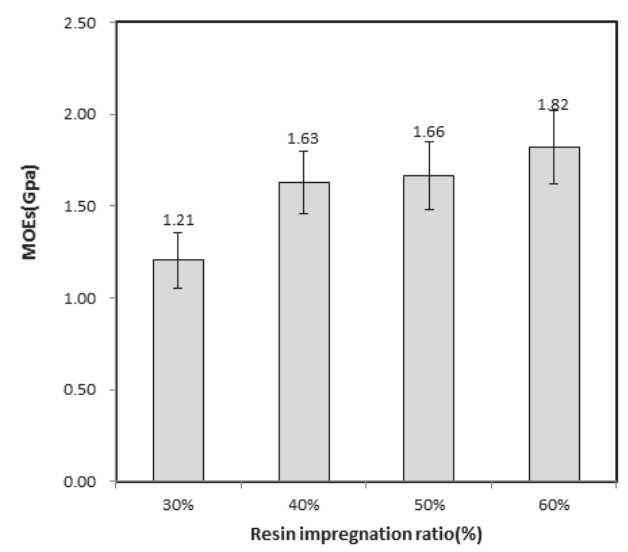

Fig. 5. MOEs of ceramics according to resin impregnation ratio at carbonization temperature $800^{\circ} \mathrm{C}$. study. These results were interpreted as the effect of insufficient bonding strength due to the nonuniform structure of rice husks and particles during the carbonization process, and a similar reason could be behind the low strength value of the ceramics in this study.

\subsection{Flexural modulus}

Table 2 and Fig. 5 show the flexural modulus values depending on the resin impregnation rate of ceramics carbonized at $800{ }^{\circ} \mathrm{C}$. The resin impregnation rates of $30 \pm 2 \%, 40 \pm 2 \%, 50 \pm 2 \%$, and $60 \pm 2 \%$ resulted in the flexural modulus of $1.21,1.63,1.66$, and 1.82 $\mathrm{GPa}$, respectively. The flexural modulus values in this study were lower than the values reported for the thinned logs of Pinus densiflora, Pinus koraiensis, and Larix kaempferi reported in Byeon et al. (2004), which were approximately $2.64 \mathrm{GPa}-7.85 \mathrm{GPa}$. This difference is believed to be caused by the difference in the characteristics of raw materials.

\subsection{Compressive strength}

Table 2 and Fig. 6 show the values of compressive strength depending on the resin impregnation rate of ceramics carbonized at $800^{\circ} \mathrm{C}$. When the resin im-

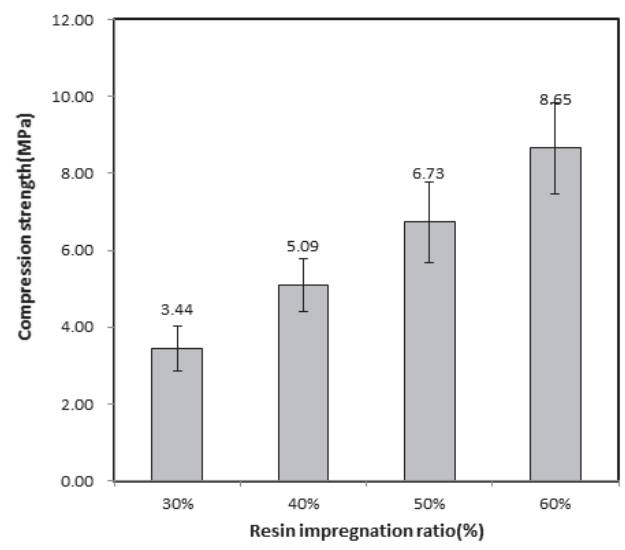

Fig. 6. Compression strength of ceramics according to resin impregnation ratio at carbonization temperature $800^{\circ} \mathrm{C}$. 
Effect of Resin Impregnation Ratio on the Properties of

Ceramics Made from Miscanthus sinensis var. purpurascens Particle Boards

pregnation rates were $30 \pm 2 \%, 40 \pm 2 \%, 50 \pm 2 \%$, and $60 \pm 2 \%$ at the carbonization temperature of $800^{\circ} \mathrm{C}$, the compressive strength values were $3.44,5.09,6.73$, and $8.65 \mathrm{MPa}$, respectively, showing that the compressive strength increased as the amount of impregnation increased. Byeon et al. (2004) also reported that the compressive strength of wood-ceramics manufactured at $70 \%$ resin impregnation rate and $600{ }^{\circ} \mathrm{C}$ carbonization temperature using thinned logs of Pinus densiflora, Pinus koraiensis, and Larix kaempferi were $3.24,7.15$, and $4.12 \mathrm{MPa}$, respectively, which were lower than the values found in this study.

\subsection{Hardness}

Table 2 and Fig. 7 show the Brinell hardness values depending on the resin impregnation rate at the carbonization temperature of $800^{\circ} \mathrm{C}$. The resin impregnation rates of $30 \pm 2 \%, 40 \pm 2 \%, 50 \pm 2 \%$, and $60 \pm 2 \%$ at the carbonization temperature of $800^{\circ} \mathrm{C}$ resulted in the Brinell hardness values of $5.11,7.15,6.85$, and $7.55 \mathrm{MPa}$, respectively, showing that the hardness also increased as the amount of impregnation increased.

Byeon et al. (2004) showed that the hardness values of phenolic resin-impregnated wood-ceramics manu-

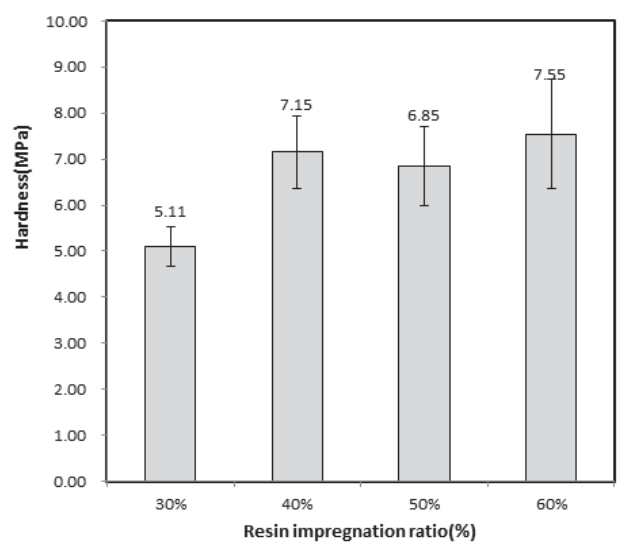

Fig. 7. Hardness of ceramics according to resin impregnation ratio at carbonization temperature $800^{\circ} \mathrm{C}$. factured with thinned logs of Pinus densiflora, Larix kaempferi, and Pinus koraiensis with carbonization temperature of $600^{\circ} \mathrm{C}$ were $15.59,11.86$, and 16.76 $\mathrm{MPa}$, respectively, showing greater hardness values than those found in this study. It is surmised that this is because the resin injected into the raw materials has a weaker penetration into the nonwood material of $M$. sinensis var. purpurascens when compared to wood with more air gaps.

\section{CONCLUSION}

In order to find a way to utilize $M$. sinensis var. purpurascens in the waterfront area, this study manufactured boards with $M$. sinensis var. purpurascens particles, impregnated them with resin, and then carbonized them to produce ceramics, after which their density and mechanical properties were examined for each resin impregnation rate.

1) The density increased from $558.57 \mathrm{~kg} / \mathrm{m}^{3}$ to $649.10 \mathrm{~kg} / \mathrm{m}^{3}$ as the resin impregnation rate increased from $30 \pm 2 \%$ to $60 \pm 2 \%$ when carbonized at the carbonization temperature of $800^{\circ} \mathrm{C}$.

2) Flexural strength performance, Brinell hardness, and compressive strength increased almost linearly as the resin impregnation rate increased at the same carbonization temperature, indicating that the resin impregnation rate had a significant impact on the mechanical properties of the ceramics made of $M$. sinensis var. purpurascens.

The wood-ceramics produced in this study showed lower strength than that of the wood-ceramics produced from Pinus densiflora, Pinus koraiensis, and Larix kaempferi. It appears that additional research would be required to improve upon this part, such as those on the manufacture of wood ceramics using a mixture of $M$ sinensis var. purpurascens and lignocellulosic. There is also a need for further research on deodorization rate, hygroscopicity, and other functional 
performances for the utilization of $M$. sinensis var. purpurascens ceramics.

\section{REFERENCES}

Byeon, H.S., Ahn, S.Y., Oh, S.W., Piao, J.J. 2004. Mechanical properties of woodceramics according to carbonizing temperature. Journal of the Korean Wood Science and Technology 32(3): 59-65.

Hirose, T., Fujino, T., Fan, T., Endo, H., Okabe, T., Yoshimura, M. 2002. Effect of carbonization temperature on the structural changes of woodceramics impregnated with liguefied wood. Carbon 40(5): 761-765.

Hwang, J.W., Oh, S.W. 2019. Change of surface temperature and far-infrared emissivity in ceramics manufactured from a board mixed with sawdust and mandarin peel. Journal of the Korean Wood Science and Technology 47(1): 66-79.

Hwang, J.W., Oh, S.W. 2020a. Properties of board manufactured from sawdust, ricehusk and charcoal. Journal of the Korean Wood Science and Technology 48(1): 61-75.

Hwang, J.W., Oh, S.W. 2020b. Mechanical performances of boards made from carbonized rice husk and sawdust: The effect of resin and sawdust addition ratio. Journal of the Korean Wood Science and Technology 48(5): 696-709.

Iizuka, H., Masimi, F., Okabe, T., Saito, K. 1999. Mechanical properties of woodceramics: A porous carbon material. Journal of Porous Materials 6(3): 175-184.

Ju, S.G., Roh, J.K. 2019. The dyeing properties of woody fiber regenerated from waste MDF by reactive dyes. Journal of the Korean Wood Science and Technology 47(2): 163-177.

Ju, S.G., Roh, J.K. 2020. Manufacturing regenerated woody dyed fiber from waste MDF using natural dyes. Journal of the Korean Wood Science and
Technology 48(2): 154-165.

Kim, D.Y., Kim, E.J., Park, H.J. 2012. Characteristics of the Vegetation Mat Prepared from Renewable Resources. 2012 Proceedings of the Korean Society of Wood Science and Technology Annual Meeting, pp. 234-235.

Lee, H.H. 1999. Development of rice hull board for the new ecomaterial. Report of ministry of agriculture, food and rural affairs.

Lee, H.H., Han, K.S. 2000. Study on the optimum pre-treatment condition for manufacture of rice hull board. Journal of the Korean Wood Science and Technology 28(3): 9-13.

Oh, S.W. 2005. Properties of woodceramics obtained by high temperatures and phenolic resin impregnation. Forest Products Journal 55(9): 27-30.

Oh, S.W., Byeon, H.S. 2002. Properties of woodceramics made from MDF. Journal of the Korea Wood Science and Technology 30(2): 115-120.

Oh, S.W., Byeon, H.S. 2005. Properties of composite boards made of sawdust and rice husk. Advance in Ecomaterial 2: 603-607.

Oh, S.W., Park, H.J., Hwang, J.W. 2012. Charactistics of board made from miscanthus sinensis var. purpuracsens particles. Journal of Agriculture \& Life Science 46(2): 43-48.

Oh, S.W., Park, H.J., Hwang, J.W. 2014. Characteristics of ceramics from miscanthus sinensis var. purpurascens particle board. Journal of the Korean Wood Science and Technology 42(3): 251-257.

Oh, S.W., Piao, J.J. 2004. Properties of woodceramics made from thinned $\operatorname{logs}(\mathrm{I})$ : Effect of resin impregnation rate and burning temperature. Journal of the Korean Wood Science and Technology 32(1): 73-79.

Oh, S.W., Park, H.J. 2010. A change in surface temperature of ceramics made from board mixed with sawdust and rice husk -Effect of resin impregnation rate and carbonization temperature-. Journal of the Korean 
Effect of Resin Impregnation Ratio on the Properties of

Ceramics Made from Miscanthus sinensis var. purpurascens Particle Boards

Wood Science and Technology 38(1): 43-48.

Okabe, T. 1996. Woodceramics. Uchida Rokakuho Publishing Co., Ltd.

Okabe, T., Saito, K. 1995. Development of woodceramics. Transactions of the Material Research Society of Japan 18: 681-684.

Park, H.J., Oh, S.W., Kim, D.Y., Kang, C.W., Wen, M.Y. 2012. Properties of Miscanthus-Wood Particle
Composite Boards. 2012 Proceedings of the Korean Society of Wood Science and Technology Annual Meeting, pp. 252-253.

Zhao B.Y., Hirose, T., Okabe, T., Zhang, D., Fan, T.X., Hu, K.A. 2002. Woodceramics prepared from wood powder/phenilated wood composite. Journal of Porous Materials 9(3): 195-201. 


\section{APPENDIX}

(Korean Version)

\section{수지함침율이 거대억새 파티클보드로 제조된 세라믹의 성질에 미치는 영향}

초록: 본 연구는 거대억새의 활용방안을 찾기 위하여 거대억새 파티클로 보드를 제조한 다음 페놀수지를 함침한 후 수지함침 율이 $30 \pm 2 \%, 40 \pm 2 \%, 50 \pm 2 \%, 60 \pm 2 \%$ 인 함침보드를 탄화온도 $800^{\circ} \mathrm{C}$ 로 탄화하여 수지함침율에 따라 밀도 및 역학적 성질을 조사하였다. 밀도, 휨강도성능, Brinell경도 및 압축강도는 수지함침율이 증가 할수록 증가하여 거대억새 파티클로 제조된 세라믹의 물리 및 역학적 성질에 영향을 주었다.

\section{1. 서론}

일반적으로 세라믹이라고 하면, 점토나 광물질을 원료로한 소결체, 즉 도기나 자기와 같은 것을 의미한다. 그러나 넓은 의미의 정의에서는 이온결합 및 공유결합을 가진 무기질 재료를 지칭하고 있다. 이에 따라 탄소도 확실히 세라믹에 포함된다. 따라서 목재와 열경화성수지 등 복합재료를 탄소화하여 얻어지는 다공질 탄소재료, 즉 목재로부터 얻어지는 세라믹을 우드세라 믹이라고 명명하였다(Okabe, 1996).

이러한 세라믹제조에 관한 연구는 Okabe and Saito(1995)가 목질재료에 페놀수지를 함침한 후 진공상태에서 열 성형시켜 새로운 다공질 탄소재료를 개발한 이래 다양한 연구가 진행되어 왔다(Hirose et al., 2002; lizuka et al., 1999; Zhao et al., 2002). 우드세라믹의 특성은 원재료의 종류 및 열경화성수지의 함침율, 탄화온도, 승온온도 등의 제조조건에 따라 물성이 다양하 며, 특히 수지함침율과 탄화온도는 우드세라믹의 밀도에 많은 영향을 주는 것으로 알려져 있다(Hirose et al., 2002; Oh et al., 2004, 2010).

한편 최근에는 목재자원의 부족으로 비목질자원을 이용한 보드 제조 및 세라믹화에 대한 연구가 수행되고 있으며, 특히 왕겨 - 목질을 혼합한 신소재 개발에 대한 연구가 진행하였다(Lee and Han, 2000; Lee, 1999; Oh and Byeon, 2005; Hwang and Oh, 2020a). 또한 다양한 부산물 및 폐기물을 활용하고자 하는 연구도 진행되었다(Hwang and Oh, 2019; Hwang and Oh, 2020b; Ju and Roh, 2019; Ju and Roh, 2020).

그 중 거대억새(Miscanthus sinensis var. purpurascens)는 리그노 셀룰로오스계 재료로 높은 다공성 저비중 지료이며, 목재와 같이 재생가능한자원으로 자원의 이용과 순환의 측면에서 매우 가치있는 자원으로 활용이 가능하다. 또한 액상페놀수지를 이용하여 제조된 억새보드가 분말상 페놀수지로 제조된 보드부다 휨강도는 비슷하였으나 박리강도는 우수하였다(Oh et al., 2012). 이러한 장점 때문에 거대억새의 유효 활용에 대한 연구가 활발히 진행중이다(Kim et al., 2012; Oh et al., 2012; Park et al., 2012; Oh et al., 2014).

따라서 본 연구에서는 21 세기 녹색 성장을 실현하는데 가치있는 자원으로 활용가능 할 것으로 판단되는 거대억새를 이용하여 파티클보드를 제조한 후 다양한 비율로 함침하여 일정한 온도에서 수지함침율별로 탄화하여 세라믹화 한 다음 밀도 및 역학적 성질을 조사하였다.

\section{2. 재료 및 방법}

\section{1 공시재료}

2.1.1. 거대억새

보드제조에 사용된 거대억새는 전남 무안 소재 ‘농촌진흥청 국립식량과학원 바이오에너지작물센터’로부터 분양받아 사용하 였으며, 보드 제조 시 시료의 균일함을 위하여 Fig. 1에서 보여진 것처럼 입자의 크기를 $10 \sim 20$ mesh로 선별하고 함수율은 $7 \%$ 이하로 조절하였다.

\subsection{2. 수지}

거대억새 보드 제조를 위하여 분말상 페놀수지(코오롱유화(주), KNB-100PL)를, 함침을 위해서는 액상 페놀수지(코오롱유화 (주), KPD-L777)을 사용 하였으며, 각 수지의 특성은 Table 1과 같다. 
Effect of Resin Impregnation Ratio on the Properties of
Ceramics Made from Miscanthus sinensis var. purpurascens Particle Boards

\section{2. 보드제조}

보드를 제조하기 위하여 균일하게 선별된 거대억새 파티클에 분말상 페놀수지를 충분히 혼합한 후 열압기의 열판위에 있는 스테인레스 정방형 몰드 속에 넣고 시료상부의 높이를 일정하게 조절한 후 열압 성형하여 $26 \mathrm{~cm} \times 26 \mathrm{~cm} \times 1.4 \mathrm{~cm}$ 의 보드를 제조하였다. 보드 제조 조건은 밀도를 $600 \mathrm{~kg} / \mathrm{m}^{3}$, 접착제 첨가량을 $10 \%$ 로 고정하여 보드를 제조하였다. 이때 열압온도는 $190^{\circ} \mathrm{C}$, 가압압력은 $3.9 \mathrm{MPa} \rightarrow 2.9 \mathrm{MPa} \rightarrow 1.9 \mathrm{MPa}(3$ 단가압), 가압시간 3 분 $\rightarrow 2$ 분 $\rightarrow 1$ 분(3단 가압시간)으로 하였다. 열압과정에서 보드의 두께를 일정하게 하기 위하여 스토퍼(distance bar)를 사용하였으며, 열에 의한 보드의 상 - 하면과 열판의 부착을 방지하 기 위하여 테프론 판을 사용하였다.

\section{3. 함침 및 세라믹 제조}

거대억새 보드를 $12 \times 12 \times 1.4 \mathrm{~cm}$ 크기로 절단한 다음 액상 페놀수지(코오롱유화(주), KPD-L777)가 들어있는 감압 함침장치 에 넣고 1 기압에서 함침율을 $30 \pm 2 \%, 40 \pm 2 \%, 50 \pm 2 \%, 60 \pm 2 \%$ 로 조절하여 함침하였다. 함침 후 시료를 건조기에 넣고 $60^{\circ} \mathrm{C}$ 에서 10 시간 $100^{\circ} \mathrm{C}$ 와 $135^{\circ} \mathrm{C}$ 에서 각각 8 시간씩 건조 및 경화시켰다. 건조한 다음 진공탄화로 $(\mathrm{KOVAC} \mathrm{KSF}-200 \mathrm{~V}$, 고려진공(주))를 이용하여 탄화온도 $800^{\circ} \mathrm{C}$ 에서 탄화하여 세라믹을 제조하였다. 이때 승온온도는 $4{ }^{\circ} \mathrm{C} / \mathrm{min}$. 이었으며, 목표온도에 서 2시간 유지한 다음 냉각시켰다. Fig. 2은 완성된 보드와 세라믹의 사진이다.

\section{4. 강도성능시험}

휨강도성능 시험용 시험편은 시편의 크기를 $110 \mathrm{~mm} \times 10 \mathrm{~mm} \times 10 \mathrm{~mm}$ 로 재단하여 항온 항습기(온도 $20 \pm 1{ }^{\circ} \mathrm{C}$, 습도 $65 \pm 5 \%$ )에서 조습처리한 후 각각의 조건별로 10 개씩 선정하고 휨강도성능시험을 실시하였다. 휨강도 시험은 KS F 2208 규정에 따라 만능강도시험기(TAESHIN, model TSU-2)를 사용하여 $0.5 \mathrm{~mm} / \mathrm{min}$. 의 하중속도로 실시하여 휨 탄성계수 및 휨강 도를 측정하였다. 브리넬 경도시험은 $40 \mathrm{~mm} \times 40 \mathrm{~mm} \times 10 \mathrm{~mm}$ 크기의 시편을 만능강도시험기를 이용하여 KS F 2212 규정에 따라 지름 $10 \mathrm{~mm}$ 의 쇠구슬을 $0.5 \mathrm{~mm}$ 의 하중속도로 우드세라믹 표면에 $1 / \pi \mathrm{mm}$ 의 깊이까지 압입하여 3 곳을 측정하였다. 압축강도 시험은 $30 \mathrm{~mm} \times 10 \mathrm{~mm} \times 10 \mathrm{~mm}$ 크기의 시편을 KS F 2206 규정에 따라 만능강도시험기를 사용하여 $0.5 \mathrm{~mm} / \mathrm{min}$. 의 하중속도로 실시하였다.

\section{3. 결과 및 고찰}

\section{1. 밀도}

밀도는 Table 2와 Fig. 3에서 보는바와 같이 탄화 전 수지함침율이 $30 \pm 2 \%, 40 \pm 2 \%, 50 \pm 2 \%, 60 \pm 2 \%$ 인 함침보드를 탄화온도 $800^{\circ} \mathrm{C}$ 로 탄화한 세라믹의 밀도는 각각 $558.57 \mathrm{~kg} / \mathrm{m}^{3}, 617.08 \mathrm{~kg} / \mathrm{m}^{3}, 627.10 \mathrm{~kg} / \mathrm{m}^{3}, 649.10 \mathrm{~kg} / \mathrm{m}^{3}$ 의 값을 보여, 같은 탄화온도에서 수지함침율이 증가할수록 탄화 후 밀도도 증가함을 알 수 있었다.

$\mathrm{Oh}$ and $\mathrm{Piao}(2004)$ 도 간벌재로 제조된 보드의 탄화 전 수지함침율이 $40 \%$ 일 때 소나무, 낙엽송, 잣나무의 우드세라믹의 밀도는 각각 $760 \mathrm{~kg} / \mathrm{m}^{3}, 730 \mathrm{~kg} / \mathrm{m}^{3}, 750 \mathrm{~kg} / \mathrm{m}^{3}$ 이었으며, 탄화 전의 수지함침율이 높은 $80 \%$ 일 때는 소나무, 낙엽송 간벌재로 제조된 우드세라믹의 밀도는 각각 $830 \mathrm{~kg} / \mathrm{m}^{3}, 840 \mathrm{~kg} / \mathrm{m}^{3}$ 의 높은 값을 나타낸 본 연구와 유사한 경향을 보고한 바 있다. 또한 라디에타 소나무로 제조된 $\mathrm{MDF}$ 를 이용한 우드세라믹 제조에서도 수지함침율이 증가할수록 밀도가 증가하는 경향을 보였다고 보고하고 있다(Oh and Byeon, 2002; Oh, 2005). 탄화 전 수지 함침율이 높을수록 탄화 후 우드세라믹의 밀도가 높아지는 것은 수지함침율이 높을수록 세포벽에 함침되어 있는 많은 양의 수지가 탄화과정에서 유리질탄소로 변환하여 세포벽을 강화시 키기 때문에 밀도가 증가하는 것으로 알려져 있다(Okabe and Saito, 1995).

\section{2. 휨강도}

Table 2 와 Fig. 4 는 탄화온도 $800^{\circ} \mathrm{C}$ 에서 탄화한 세라믹의 수지함침율에 따른 휨강도 값을 나타내었다. 탄화온도 $800^{\circ} \mathrm{C}$ 에서 수지함침율이 $30 \pm 2 \%, 40 \pm 2 \%, 50 \pm 2 \%, 60 \pm 2 \%$ 일 때 휨강도 값은 각각 $2.76 \mathrm{MPa}, 3.25 \mathrm{MPa}, 3.30 \mathrm{MPa}, 3.74 \mathrm{MPa}$ 을 나타내어 밀도 경우와 유사하게 수지함침율이 높아질수록 거의 직선적으로 증가하는 경향의 휨강도를 나타내었다.

이러한 경향은 라디에타 소나무로 제조된 $\mathrm{MDF}$ 를 이용한 우드세라믹 제조에서도 수지함침율이 증가할수록 휨강도가 직선적 으로 증가하였다는 보고(Oh and Byeon, 2002; Oh, 2005)와 일치한다. 또한 수지 함침율과 탄화온도조건에서 수종의 밀도에 따른 차이가 나타났는데 비슷한 수지 함침율조건 $40 \%, 60 \%, 80 \%$ 에서 탄화온도 $600^{\circ} \mathrm{C}$ 조건의 라디에타소나무의 경우의 휨강도 는 각각 $6.96 \mathrm{MPa}, 8.04 \mathrm{MPa}, 13.44 \mathrm{MPa}$ 정도의 값으로 거대억새 파티클을 사용한 본 연구의 경우보다 높은 값을 나타내었다. 
그리고 Oh and Byeon(2005)은 톱밥과 왕겨로 제조된 혼합세라믹의 탄화온도 $600^{\circ} \mathrm{C}$ 에서 페놀수지 함침율이 $40 \%, 50 \%, 60 \%$, $70 \%$ 일 때 휨강도의 값은 각각 $4.70 \mathrm{MPa}, 4.90 \mathrm{MPa}, 5.98 \mathrm{MPa}, 6.08 \mathrm{MPa}$ 을 나타내었다고 보고하였는데, 이 값은 본 연구의 세라믹의 강도 값보다도 약간 높은 값이다. 이러한 결과는 탄화과정에서 왕겨와 파티클의 불균일한 조직으로 인하여 충분한 결합력을 갖지 못했기 때문으로 해석 하고 있는데, 본 연구의 세라믹의 경우에도 이와 유사한 원인으로 낮은 강도 값을 나타낸 것으로 생각된다.

\section{3. 휨 탄성계수}

Table 2 와 Fig. 5 는 탄화온도 $800^{\circ} \mathrm{C}$ 에서 탄화한 세라믹의 수지함침율에 따른 휨 탄성계수 값을 나타내었다. 수지 함침율이 $30 \pm 2 \%, 40 \pm 2 \%, 50 \pm 2 \%, 60 \pm 2 \%$ 일 때 휨 탄성계수의 값은 각각 $1.21 \mathrm{GPa}, 1.63 \mathrm{GPa}, 1.66 \mathrm{GPa}, 1.82 \mathrm{GPa}$ 을 나타내었다. 본 연구의 휨 탄성계수의 값은 Byeon et al.(2004)이 보고한 소나무 잣나무 낙엽송 간벌재의 값 약 $2.64 \mathrm{GPa}-7.85 \mathrm{GPa}$ 보다 작은 값을 나타내어 원재료의 특성차이에 기인된 것으로 생각된다.

\section{4. 압축강도}

Table 2 와 Fig. 6에 탄화온도 $800^{\circ} \mathrm{C}$ 에서 탄화된 세라믹의 수지함침율에 따른 압축강도 값을 나타내었다. 탄화온도 $800^{\circ} \mathrm{C}$ 에서 수지함침율이 $30 \pm 2 \%, 40 \pm 2 \%, 50 \pm 2 \%, 60 \pm 2 \%$ 일 때 압축강도 값은 각각 $3.44 \mathrm{MPa}, 5.09 \mathrm{MPa}, 6.73 \mathrm{MPa}, 8.65$ $\mathrm{MPa}$ 을 나타내어 수지 함침량이 많아질수록 압축강도가 증가하였다. Byeon et al.(2004)도 소나무, 잣나무 낙엽송 간벌재를 이용하여 수지 함침율 $70 \%$, 탄화온도 $600{ }^{\circ} \mathrm{C}$ 로 제조한 우드세라믹의 압축강도가 본 연구의 값보다는 낮은 $3.24 \mathrm{MPa}, 7.15$ $\mathrm{MPa}, 4.12 \mathrm{MPa}$ 을 보고한 바 있다.

\section{5. 경도}

Table 2 와 Fig. 7에 탄화온도 $800^{\circ} \mathrm{C}$ 에서 수지함침율에 따른 Brinell 경도 값을 나타내었다. 탄화온도 $800^{\circ} \mathrm{C}$ 에서 수지함침율이 $30 \pm 2 \%, 40 \pm 2 \%, 50 \pm 2 \%, 60 \pm 2 \%$ 일 때 Brinell 경도 값은 각각 $5.11 \mathrm{MPa}, 7.15 \mathrm{MPa}, 6.85 \mathrm{MPa}, 7.55 \mathrm{MPa}$ 을 나타내어 페놀수지 함침량이 많아질수록 경도도 증가하였다.

Byeon et al.(2004)은 간벌재로 제조된 페놀수지함침 우드세라믹의 탄화온도 $600^{\circ} \mathrm{C}$ 에서 제조한 소나무, 낙엽송, 잣나무의 우드세라믹의 경도 값은 각각 $15.59 \mathrm{MPa}, 11.86 \mathrm{MPa}, 16.76 \mathrm{MPa}$ 을 나타내어 본 연구의 경도 값보다 큰 값을 보였는데 원재료에 주입되는 수지의 침투력이 공극이 많은 목재보다 비 목질재료인 거대억새가 약하기 때문으로 추측된다.

\section{4. 결론}

수변공간에 조성되어 있는 거대억새의 활용방안을 찾기 위하여 거대억새 파티클로 보드를 제조한 후 수지를 함침한 다음 탄화하여 세라믹을 제조하고 수지함침율 별로 밀도 및 역학적 성질을 조사하였다.

1) 밀도는 탄화온도 $800^{\circ} \mathrm{C}$ 로 탄화하였을 때 수지함침율이 $30 \pm 2 \%$ 에서 $60 \pm 2 \%$ 로 증가함에 따라 $558.57 \mathrm{~kg} / \mathrm{m}^{3}$ 에서 649.10 $\mathrm{kg} / \mathrm{m}^{3}$ 로 증가하였다.

2) 휨강도성능, 브리넬경도, 압축강도 등은 같은 탄화온도에서 수지함침율이 증가함에 따라 거의 직선적으로 증가하여 수지함 침율이 거대억새로 제조된 세라믹의 역학적 성질에 큰 영향을 주었다.

본 연구에서 제조된 우드세라믹은 소나무, 잣나무, 낙엽송으로 제조한 우드세라믹보다 강도적인 부분이 낮은 값을 나타내었 다. 이 부분을 개선하기 위하여 거대억새와 목질재료를 혼합한 우드세라믹 제조등에 관한 추가연구가 필요할 것으로 보인다. 또한 거대억새 우드세라믹의 활용을 위하여 탈취율, 흡습성등과 같은 기능적인 성능부분에 관한 추가연구가 필요할 것으로 보인다. 